\title{
The Meaning Making of an Environmental Movement: A Perspective on Sedulur Sikep's Narrative in Anti-Cement Movement ${ }^{12}$
}

\author{
Primi Suharmadhi Putri
}

Received: 1 November 2017 | Accepted: 5 December 2017 | Published: 18 December 2017

\begin{abstract}
This article discusses the narratives of Sedulur Sikep on their recent movement in rejecting cement companies in Central Java. For the Sedulur Sikep with their culturally-distinct traits through their spirituality, their human-nature relationship, as well as their stance toward the authorities, have strongly permeated the contemporary anti-cement movement. This study then perceives Sedulur Sikep as a peasant community that treats land and resources as their medium in expressing spirituality as well as in perpetuating their resistance to the authorities. Therefore, the respective Kendeng Mountains play an important role in building the narratives of the anti-cement movement that is strongly influenced by Sikep doctrines, and additionally building the meaning behind Sedulur Sikep's environmental movement that is actually struggling for free access to and utilisation of common resources.
\end{abstract}

Keywords: Sedulur Sikep; peasant; anti-cement movement; Kendeng Mountains.

\section{Introduction}

The heated anti-cement movement in northern-central Java for almost a decade has championed the Samin people, who prefer to be called as Sedulur Sikep (Widodo, 1997), and are populating the Kendeng Mountains in Pati-Central Java. Sedulur Sikep becomes

\footnotetext{
Data and analysis of this article are part of author's thesis at the University of Oslo. The author wishes to thank The Norwegian State Educational Loan Fund and Centre for Development and The Environment (SUM) - University of Oslo for the research fund, as well as to Professor Desmond McNeill, Kenneth Bo Nielsen, and Kari Telle for the inputs and thoughts on the research.

2 The anti-cement movement is well-known as "Network of the people who care about the Kendeng Mountains" (in Bahasa Indonesia, Jaringan Masyarakat Peduli Pegunungan Kendeng, abbreviated JMPPK), however this article will only use the anti-cement movement in order to emphasis on Sikep's narrative, rather than the JMPPK's narrative, which not all Sikep community members join in the network, yet they still support the idea of the anti-cement group.
} 
a new idol in many narratives of the anti-cement movement in Central Java, both in popular media and academic products, that refer to the anti-cement movement as the 'Samin movement'. This strong narrative of Sedulur Sikep started in 2005 when Sedulur Sikep instigated a movement in rejecting PT. Semen Indonesia, previously PT. Semen Gresik, to build their cement company in Pati and start exploiting the karstic Kendeng Mountains (Crosby, 2013).

However, the movement did not stop until the Supreme Court in May 2009 ruled in favor of the people's lawsuit that annulled PT. Semen Gresik's license to build its industry in Sukolilo-Pati. Keeping their promises to protect the Kendeng Mountains, the Sedulur Sikep are currently assisting two other areas close to their village that are also threatened by incoming cement industries. Through their anti-cement activism, the Sedulur Sikep thereby are conserving both their identities as a peasant people that are bound to land and water availability as well as the followers of Mbah Samin's teachings, known as Sikep doctrines.

Sedulur Sikep perceives the Kendeng Mountains as more than a physical landscape; its possession of material and nonmaterial elements is crucial for peasantry's socio-economic traits. More importantly, this study finds the Kendeng Mountains play an important role in expressing Sikep doctrines that are related to the human-nature relationship. Also, as common resources, the Kendeng Mountains have shaped the narratives of Sikep teachings with regards to their view on external authority. Accordingly, the traits of the Sedulur Sikep in Pati have become clearly canvassed when the Kendeng Mountains became 'threatened' by the incoming cement industries.

This article attempts to explore the meaning-making behind Sedulur Sikep's environmental movement that is often being neglected in many researches, particularly in the recent case of the anti-cement movement in Central Java. Research on Sedulur Sikep re-flourished within the past decade as responses to their involvement in the anticement movement. However, the majority of these prior researches 
have been more focused on the anti-cement activities that are said to be actuated by Sedulur Sikep in Pati. By only presenting historical aspects of the Samin Surosentiko's movement in resisting resource capitalization during the Dutch colonial period, there is lack of explanation on the relationships between the ideology of Samin Surosentiko, known as Sikep doctrines, on his followers' attitude toward environmental and ecological balances, especially in regards to perpetuating their spiritual beliefs toward the earth. Thus, this article then scrutinizes the core teaching of Sikep doctrines which is Agama Adam, as their primary spiritual belief, that is defined by the human-nature relationship.

Using an interdisciplinary approach in conducting the research, the researcher emphasised the anthropological approach. This approach was chosen in order to have a thorough understanding of both Sikep doctrines and Agama Adam. Data obtained from interviews, secondary resources, observations through a short livein were able to clarify and validate each other through triangulation of rich ethnographic data.

Research findings show that there is a complex relationship between Sikep's doctrines and other elements of their social and cultural system. In regards to the human-nature relationship perceived by Sikep doctrines, their view on resource management further draws the power relations between Sedulur Sikep and the authorities, that has become the base of Sedulur Sikep identity and narratives that have existed since the colonial period. These elements then must be taken into account to fully understand the Sikep's narrative on their struggle to protect the environment from the excessive exploitation of the cement industry. Furthermore, King (1973) argued in his analysis of Sikep core spiritual beliefs, the Agama Adam, that such beliefs may also promote solidarity and enable Sedulur Sikep to withstand the pressure of external authority. This article then uses the contemporary case of the capitalistic cement industry that is threatening the Kendeng Mountains as spiritual resources to reflect on King's argument. 
In order to explore the aforementioned issue, this article will be divided into several sections and a conclusion part. First, this article will discuss the narratives of Samin and his followers in its initial phase during the Dutch colonial period, and how the new regulations imposed by the colonial administrative provoked the Samin movement. Second, this article will argue that the Samin movement is a peasant movement, derived from the cause of their movement that was the attempt of colonial administrative to capitalise the land and other common resources, which used to be the peasants' means of production. Third, reflecting form the previous two sections, this section will scrutinise Sedulur Sikep's views on spirituality and the human-nature relationship as foundations on the meaning making of their environmental movement to protect their resources, and will be further explored in the next section. Fourth, this section explores more deeply on the anti-cement movement, which became the core activity in protecting Kendeng Mountains as a source of spiritual power for adherents to Sikep doctrines as well as Agama Adam.

\section{Understanding the Movement's Narratives of Samin Surosentiko and his Followers}

To understand the underlying reasons behind Samin's movement, it is necessary to reflect on the broader context of colonialisation in Java, particularly the closure of forest regions. Policy on the closure of common resources, such as teak forests, often contributed to peasant protests that ended in violent clashes with forestry officials and the police (Korver, 1976; Peluso, 1992). The new colonial policies, which were a foreign system imposed on the villagers, had a profound impact on the traditional system of common resource management. Furthermore, Peluso (1991) also emphasised that the changes of conditions did cause and jeopardise the villagers' poor condition, who were used to gathering forest products as their source of living. When Samin expressed his view 
that resource management should be based on values of equality and without outside intervention, his ideas were embraced by those who were negatively impacted by the colonial policies (Shiraishi, 1990).

Samin Surosentiko was born in 1859 in a village close to Randublatung in the southern part of Blora Regency. Samin Surosentiko's activism in the poor peasant movement for their cause was inherited from his father, Raden Surowidjojo, who was disappointed by the people's poor condition and how they suffered under Dutch colonialism. In 1890, Samin Surosentiko started to recruit followers from his village and neighbouring villages by preaching his views of resistance. Emphasising against colonial regulations of taxation and control over resources, Samin and his teachings became popular among poor peasants. The fact that this movement first emerged in a teak forest played a crucial role in defining the movement's idealism, especially its view on common resource governance. The movement began as an expression of the demand for the restoration of free access to the teak forest in Blora and the surrounding region (Korver, 1976). As such, economic factors are important in analysing the development of his movement (Benda \& Castles, 1969; King, 1973).

In the beginning, Samin and his followers remained a local rural movement and did not catch the attention of colonial administrators until it grew into a larger peasant movement that caused disruption to the Dutch bureaucratic system (Benda \& Castles, 1969). Benda and Castles state that some Indonesian scholars confidently view Saminism as a manifestation of indigenous socialism, peasant virtues, and patriotic resistance to colonialism (1969, s. 209). Emphasising 'patriotic resistance to colonialism', the post-colonial government further perceived the movement as a nationalist one in terms of its resistance to colonialism, claiming that the Samin community had successfully assimilated into the newly-independent Indonesia (King, 1973, s. 460). However, the Samin movement did not cease when the colonial period ended, 
which puzzled both the administrators of the Indonesian Republic and their Dutch predecessors (Benda \& Castles, 1969, s. 209). The Samin movement's persistence was driven by their rejection of most colonial regulations, such as taxes and forest management, which were upheld by the post-colonial administration. Thus, the Samin movement cannot be categorised merely under the guise of nationalism.

Meanwhile, the common Javanese villagers have divergent perceptions on Samin's followers or Sedulur Sikep, in part due to Dutch administrators creating a disparaging image to limit the spread of Samin's teachings and prompting the rest of villagers to shun the movement, and in part due to Samin's followers own withdrawal from the common village system and its social life (Benda \& Castles, 1969; Korver, 1976; King, 1973). The latter was triggered by the core of Samin's teachings, 'Agama Adam', which is considered a puritanical manner for both the Javanese and peasants. Korver (1976, s. 252), using a millenarian perspective, saw Sedulur Sikep detachment as part of the foundation of a perfect society exclusively for those adherents to the movement or faith. This utopianism then enforced their sectarian attitude, with a crucial dividing line between the millenarian leader's followers (that is, Samin's followers) and non-followers (Korver, 1976).

Another important aspect to be taken into account regarding Samin's followers' sectarian behaviour is closely related to their view on being 'pure' Javanese by rejecting the 'alien belief system' (King, 1973, s. 460). Such a system would include being subject to the Dutch colonial system by paying taxes or accepting and following the enforced socio-political system, as well as any 'imported' religious beliefs. Korver also highlighted the millenarian aspects of the Samin movement, such as its members' relationships with spirituality, Javanese puritanical virtues, and peasant tradition, that have triggered a resistance to authority and activism to claim resource rights. Korver writes: 
"Core of Samin's teachings was so-called 'faith of Adam', a form of natural religion of which veneration of the earth and a high estimation of the role of peasant society were important features. Further, Samin's teachings are marked with distinct puritanical traits: Stealing, lying, and adultery were forbidden to Samin's followers. Women, like the peasants, were also held in high respect. [...] Economically and politically the following goals were pursued by the Samin movement: Restoration of the freedom to access forests and other common lands (resources), and the abolition of taxes and statue labor [...] Generally speaking they recognized no authority and displayed a tendency to withdraw from village society". (Korver, 1976, s. 250)

While Benda and Castle highlighted the relationship of 'Faith/ Religion of Adam' with the existence of authorities as follows:

"The religion of Adam, that is to say, was not only a pre-Islamic but alsoif only unconsciously-a pre-Hindu-Buddhist ethic: It harked back to a 'pure' Java, unsullied by all foreign authority intrusions. Since the authorities confronting the Saminists were prijaji, with their Dutch bureaucrat masters and their Muslim bureaucrat subordinates, they could easily have come to see colonialism, Islam, and Hindu-derived prijaji values as part of a single, alien, and hierarchical establishment from which they sought to escape". (Benda \& Castles, 1969, ss. 234-235)

In addition to state (Dutch colonial) authorities, Sedulur Sikep also perceived other forms of authority that needed to be banished, since they would interfere with any traditional way of living perceived by Sedulur Sikep individuals, such as the 'imported' religious beliefs.

Looking at the late Samin Surosentiko and his followers' goals from the movement's early formation until its present status as a Javanese millenarian movement ${ }^{3}$, Kartodirdjo (1972) argued that these goals represented the same classic response to threatened traditionalism resulting from exposure to a pre-colonial 'foreign

\footnotetext{
Perceiving the Sedulur Sikep movement as millenarianism would, in this research, be best understood from the existence of 'Sikep ideology' preached by Samin Surosentiko, who was once regarded as 'The Savior' or in Javanese context as Ratu Adil - Just Ruler. Another millenarianism movement that emerged around the same time as Saminism was 'Sarekat Islam', which was high in modernity, populated by scholars, and had significantly more advanced political action against the Dutch colonials at the local level (Korver, 1976, p. 264).
} 
system', such as the Islamic tradition brought by Arab (and later Indian) traders as well as western domination through colonialism which were perceived to undermine the existing traditional economic and political systems. The existing traditional economic and political systems here can be perceived as the local identity of Javanese peasants, which happened to fit with their spirituality and the desire for a pure Java, unsullied by all foreign authority intrusion (King, 1973, p. 473).

Accordingly, within peasant communities, the millenarian movement pursued the restoration of an indigenous traditional order and sought to reassert traditional identity (Kartodirdjo in Scott, 1977). For rural native peasants, this traditional identity was strongly based on a connection to the land and soil as a livelihood, including the tradition of producing their own food based on the principle of total self-sufficiency without foreign intervention. Scott (1977) concluded that this (puritan) peasant trait should be associated with the peasants' daily matters both within and between communities:

"Though by no means isolated from large society, local peasant communities stubbornly retained their own identity which was bound up with attachment to the soil and to age-old village cults... moreover ... the central village values of cooperation and reciprocal help were prized because they allowed the village community to function as a more or less self-contained unit and were thus without outside reference". (Scott, 1977, s. 213)

Thus, the importance of land/soil in defining identities and traditions has led to the Samin movement and its activist actions having a stronger association to its land cultivation by peasants and its efforts to retain this identity. In addition, the way of living without outside influence also played a significant role in the movement's resistance, identity, and traditional struggles.

Michael Adas (1981) saw Samin's demand as a communalistic social organisation based on the economic equality of individuals and on the common possession of the land and its products. According 
to Samin Surosentiko's principle, Javanese should be the only entity entitled to rule and govern the island of Java, which eventually Dutch colonial enforced new taxes and regulations on resource management that contradicted the traditional communalistic system of governing. Therefore, Sedulur Sikep pledged to run their lives based on the teachings of Mbah Samin Surosentiko, particularly in observing Agama Adam, that served to promote solidarity and to enable them to withstand the pressure of external authority, which accordingly after the independence became the ramification of their resistance to Indonesian government authority (King, 1973, ss. 473-474). They also intend to protect their children from state indoctrination on any ideologies and religious beliefs besides Sikep teachings and Agama Adam, by refusing to send their children to formal institutionalized schools, whereas Sedulur Sikep believes that children are parents' responsibility to teach their children manners, benevolence, and life skills as a future peasant.

\section{Saminism as Peasant Movement}

A colonial government investigation in $1917^{4}$ found that the primary cause of the Samin movement was the peasants' grievances in the face of new 'enforced' regulations. These included taxes, new land tax regulations, new enforced duties intended to benefit peasants (but not appreciated by them), such as tax-funded village banks, schools, night watchmen, bull studs, and irrigation regulation, as well as the surrender of land in the support of the village schoolteacher, and forestry regulations rendering the procurement of traditional wood more difficult (Kahin, 1955). The government investigation found that access to resources and bundles of new regulations also contributed to the attitudes of much of the Indonesian peasantry

\footnotetext{
The Dutch Colonial's Administration published a comprehensive official report: Verslag betreffende het onderzoek in zake de Saminbeweging ingesteld ingevolge het Gouvernements besluit van 1 Juni 1917, No. 20 (Batavia, 1918). Authored by Asst. Resident J. E. Jasper, after he was assigned to investigate Samin's followers in Blora. Therefore, the report was later known as the 'Jasper Report'.
} 
at the time, though in a less articulated and more passive way than among Samin followers.

Kahin (1955, ss. 43-44) highlighted that the movement developed 'anarchistic' tendencies in the way that members refused to pay taxes or perform corvées, or other new legally-required village services that members sought to avoid. However, this form of disobedience toward the colonial government-that is, avoiding open attacks or institutional confrontations, withdrawing from the village's system, and focusing on self-help-showed to some degree that Samin and his followers were practicing what Scott would categorize as 'everyday forms of resistance'. Scott (1985, p. 29) argues that everyday forms of peasant resistance are the prosaic but constant struggles between the peasantry and those who seek to extract labour, food, taxes, rents, and interest from them, which in this case can be a wide range of actors from formal state administrators and bureaucrats to informal property owners, money lenders, or local strongmen. Accordingly, farmers who acted based on everyday forms of resistance were consciously denying the claims made by one or more types of superordinate classes or other traditionally powerful actors (Scott, 1985, p. 33).

Even though Scott also argues that the movement was largely driven by lower classes struggling against superordinate classes, the Sedulur Sikep movement cannot merely be classified as everyday forms of peasant resistance. First of all, not all poor peasants submitted to Samin's ideology that the movement initiated and was preached by middle-class peasants. Second, Samin and his followers had never been subject to any labour or wage systems, which were one of the most prominent causes of everyday forms of resistance.

Thus, understanding the Samin movement, particularly in the context of Sedulur Sikep's contemporary anti-cement movement, is not possible by only perceiving the members' economic status as lower-class 'poor' peasants, nor their obvious actions of resistance alone. A prominent part of Sedulur Sikep's actions of resistance is conditioned by intentions, values, and purposefulness, which 
can be described as an expression of their 'consciousness' (Scott, 1985; see next page). To understand their consciousness, this article derives Scott's (1985, pp. 37-38) description on the pattern of 'everyday resistance' as a distinct behaviour with far-reaching implications. The implied meaning, they give to every act-the symbols, the norms, the ideological forms they create-constitutes an indispensable background to define their behaviours (Scott, 1985). The discussion, therefore, merits a reflection on the complicated relationship between the thoughts and actions of the Sedulur Sikep.

The points that need to be pinned down in order to understand the relationship between thoughts and actions become related if both elements are in constant communication. To explain the complicated relationship between the two, Scott (1985, p. 38) emphasised their influence toward one another, in which acts born of intention influence consciousness, which then influences subsequent intentions and acts. Thus, acts of resistance and thoughts about (or the meaning of) resistance are in constant 'dialogue'. Scott also points to another circumstance on the existence of consciousness to explain one's intentions and actions:

"Intentions and consciousness are not tied in a quite same way to the material world as behaviour. It is possible and common for human actors to conceive of a line of actions that is, at the moment, either impractical or impossible. Thus, a person may dream of a revenge or a millennial kingdom of justice that may never occur. On the other hand, as circumstances change it may become possible to act on those dreams. Hence, the realm of consciousness gives a privileged access to lines of action that may-just may-become plausible at some future date". (Scott, 1985, p. ibid)

The possibility of impractical or impossible action due to peasants' imagination of a millennial kingdom-or the 'golden age'which is centralised in millenarian movement, was transformed into the consciousness of the peasants, especially those who were linked to the millenarian movement. Therefore, Sedulur Sikep's intentions, ideas, and languages of their resistance are part of their consciousness to achieve the so-called 'golden age'. 
As Korver (1976) argues on the pursuit of the millennial kingdom-or the 'golden age'-by peasants, in this context, is the Sedulur Sikep movement. That is the desire to live without any superordinate actors, elites, or authorities who use their power to impose their own image of 'the right' social order, and the need to abolish such imposed power altogether. The Sikep's consciousness of the elites promoting their own ideals justified not only the behaviour but also the consciousness of the non-elites or the subordinate classes. This played a vital role in Sedulur Sikep's action of withdrawing themselves from the Javanese village system that, based on what Sedulur Sikep believed was being exposed to a foreign influenced system and accepting it as their own (new) system, such as accepting the hegemonic religious or social ideology as a normal or even justifiable part of the social order (Scott, 1985, p. 39). Hence, the idealism of Sedulur Sikep living their lives without any interference from authority imposing a foreign system formed the backbone for the notion of establishing their own social order.

The peasantry culture of the Sedulur Sikep, especially in understanding the resistance movement, is largely derived from their experiences resisting the enforced non-native system or social order by elites or superordinate classes of authorities. Scott ${ }^{5}$ (1985, p. 41) vividly captured the process:

"By referring to the culture that peasants fashion from their experiencetheir 'offstage' comments and conversation, proverbs, folksongs, and history, legend, joke, language, ritual, and religion-it should be possible to determine to what degree, and in what ways, peasant actually accept the social order propagated by elites".

The Sedulur Sikep's experiences tolerated a very small degree of acceptance of the concerted social order, yet they aimed to conserve their tradition of resistance toward any authority's interference.

Scott's research in this book focused on peasants in Sedaka, Malaysia. However, he also referred to the Saminist' peasant movement by calling them a lower-class religious sect as one sample of peasant culture that abandoned the hierarchy of the nobility/elites. 
Lower-class [religious sect] culture explanation of this case is highly dependent on the high degree of consciousness behind every action of resistance toward the elites-be it the Dutch colonial state or the Indonesian post-colonial state-that enforced their vision of social order and sought to control the ideological sectors of a society.

Finally, according to Benda and Castles (1969) and Scott (1977), by declaring that 'land, water, and wood are the property of all' and insisting that what is taken from the earth is their prescriptive right, Sedulur Sikep followers exhibit a type of Javanese socialism that defends local subsistence rights. This way of viewing Sedulur Sikep indeed works contrary to both the colonial system and the post-colonial system's natural resource management.

\section{Sedulur Sikep's Views on Spirituality and Human-Nature Relationship}

The whole concept of Sedulur Sikep in perceiving the earth and ecological balances is closely related to how Sikep doctrine observes women within the Samin community. Sedulur Sikep is monogamous according to Sikep's principle that 'siji kanggo sak lawase'-one (woman) forever, by which a man cannot divorce his wife regardless of the reason. Yet, this does not apply when death takes part, then the widow is allowed to form another union. In addition to such full loyalty expected from their husband, the Sikep woman is highly respected by others, in addition to being respected under the spiritual belief of venerating the 'mother-earth'. A woman (mother) is a manifestation of earth, the giver, nurture, and life protector, therefore Sedulur Sikep believes that women are relatively more affected by any form of environmental degradation due to their direct contact with the earth, such as their domestic life matters related to water, food, household affairs, family nurturing, livestock, and agricultural activities (Candraningrum, 2014; Susanto, 2016).

According to a Sikep's elder in Pati, with regards to Agama Adam's way of praying and observing spirituality, the Sedulur Sikep in Pati use all elements within Kendeng: Water, vegetation, 
animals, and non-material elements such as the symbolization of their life giver, Mother Earth. Some sacred sites used by the Sedulur Sikep to have meditation-like rituals or prayers to God for specific purposes, as well as the water springs and caves that irrigate Sikep houses and rice fields receive special blessings and offerings. This way of treating the elements of the Kendeng Mountains, especially those that directly benefit the people, is hoped to help maintain and conserve their sustainability and express the people's gratitude to Mother Earth.

Hence, understanding the Kendeng Mountains through Sedulur Sikep's view can be understood not only as a way of conserving their identity as Samin's followers, but also as a mode of spiritual expression, especially to Mother Earth. With regards to their belief of Agama Adam, which emphasizes the human-nature relationship, their belief inevitably transformed the land into an element that is beyond a means of production, where land plays a pivotal role within the cultural and spiritual aspects of Sedulur Sikep. The importance of spiritual beliefs in subjecting oneself as an adherent of Sikep teachings, the quality of the Kendeng Mountains are important for the continuity of their tradition for the future generations of peasants. Thus, their anti-cement activism is further seen as a political consciousness that is connected to their spirituality upon the land where, according to Escobar (1995, s. 96):

"At the basis of the peasant model is the notion that the Earth 'gives' based on its 'strength' [...] There is a relation of give and take between humans and the earth, modelled in terms of reciprocity and ultimately validated by Providence (God) [...] Food crops draw their strength from the land; humans in turn, gain their energy and force from food crops and animal products, and this strength, when applied as work on the land, yields more force. Work, construed as concrete physical activity, is the final 'using up' of the land's strength".

Therefore, with regards to the Sedulur Sikep anti-cement movement, their spirituality here plays a role in 'creating power' to assist their effort to build an oppositional movement (Pulido, 1998) 
against the external authority in the form of capitalistic resource exploitation by the state-business alliance. Borrowing Escobar's (1995) arguments on power, this paper contends that power created by Sikep's spirituality here can be perceived as the give and take reciprocity between human and the earth. Human's power here comes from earth in the form energy and force from food crops and animal products, and this strength is applied as work on the land. According to Sedulur Sikep, this simple cycle of reciprocity, that is validated by their Providence-in a way they are perceiving the Mother Earth as giver-will be broken once the extractive cement company started to capitalize and exploit the respective Kendeng Mountains, as the mountains are significant in providing water for the land and the people. Furthermore, reflecting on King (1973) on his view of Sikep spiritual beliefs, the Agama Adam, that such beliefs may also promote solidarity and enable Sedulur Sikep to withstand the pressure of external authority. This article then uses the contemporary case of the capitalistic cement industry that is threatening the Kendeng Mountains as spiritual resources to reflect on King's argument.

The Sikep notion of management and access to common resources, such as the Kendeng Mountains, can be explained by tracing back to the early stages of the Samin movement. The demands of the movement, both then and now, are free access to and utilisation of common resources. Thus, through their persistence in protecting the Kendeng Mountains, Sedulur Sikep in Pati preserves their Sikep traits of equality and freedom to access the common resources, which these common resources are now in a position to be used exclusively and by the authority in power, that is the state collaborating with private sectors. Thus, their way of pursuing the Kendeng Mountains at a whole new level by instigating the anti-cement movement can be perceived as an expression of their rejection of external authority, which through the cement industry will interfere and disrupt their very own Sikep's teachings, especially as farmers and adherents of Agama Adam. 
Conflict over natural resource management in the Kendeng Mountains first arose when PT. Semen Gresik decided to build their new factory in southern Pati. Sedulur Sikep as peasants who live in the area will inevitably be impacted by any new industrial activities. Realising that the consequences are also long-term, they took this opportunity to demand resource management as part of their economic and cultural capital.

Their concern over the exploitation of the Kendeng Mountains' by the capitalistic cement industry became a turning point for them to start the anti-cement movement and collaborate with their fellow non-Sikep neighbours. Thus, their way of protecting the Kendeng Mountains at a whole new level by instigating their fellow non-Sikep neighbours has become a powerful way to gain more support for the anti-cement movement as an expression of their rejection of external authority, which through the cement industry will interfere and disrupt their very own Sikep's teachings, especially as peasants and adherent of Agama Adam. Later, this movement became a space for the Sedulur Sikep to popularise their concepts of environmental protection and resource management, and to defend their freedom from external authority, that in this case is the government allied with business.

\section{Sedulur Sikep on the Recent Anti-cement Movement}

The Sedulur Sikep's way of expressing their rights to the land and natural resources was build upon on their grievance for the loss of access to resources as well as limitations or regulations on their land possession (Ross, 2017). The values of the land and other resources pursued by the Sedulur Sikep are attached to their peasantry virtues. As true followers of Samin Surosentiko and adherents of Sikep teachings, the only livelihoods allowed for Sikep members are from toiling the land. Sikep teachings rarely or never specify compulsion on specific territorial or geographical location on their land to maintain the virtues as Javanese peasants, such that 
the availability of land become the only elements to observe and conserve their peasant Sikep traits.

Without downgrading the significances and meanings of the Kendeng Mountains perceived by the local farmers, and prominently by the Sedulur Sikep, the respective Kendeng Mountains' physical qualities are strongly related to its function as a water catchment area (JMPPK, 2015). Land and water availability is necessary to Sedulur Sikep who consider themselves as the upholders of Javanese peasant traditions. The exploitative nature of the cement company that is threatening Kendeng Mountains, can be argued as the main trigger that nudges Sedulur Sikep to refuse the cement companies along with the industry's environmental impacts.

Although their initial rejection of the cement industry started in Sukolilo-Pati, the movement has spread out to other districts and regencies that are also threatened by big cement companies. Thus, since the movement has grown and extended to other regions, the numbers of local non-Sikep farmers joining and dominating the movement have also grown. However, despite the varied backgrounds of people who have joined the movement, the recent case of the anti-cement movement has given them the opportunity to induct Sikep's narratives regarding the Kendeng Mountains to everyone who has joined the movement. It was said that Sedulur Sikep is not against the idea of cement and concrete, as they also need it in their life. Thus, their idea of forming the anti-cement movement is to reject the exploitative cement industry in Kendeng Mountains, and more generally in Java Island. This is based on their idealism that Java, particularly Central Java, should be championed by agricultural sectors, where farmers' role is important to the Island's development.

Therefore, rooted back from the early age of their movement, the contemporary Sikep's anti-cement movement still maintains its main principles. Thus, the anti-cement movement, which was initiated by a group of concerned Sedulur Sikep in Pati, claimed it to be one of their ways to preserve their Sikep doctrines and Agama 
Adam. With strong influence from prominent Sikep figures such as charismatic Gunretno and Gunarti of Pati, the anti-cement group perpetuates some Javanese peasant of Sikep virtues carried out within anti-cement group movement strategies, but also accommodating other values believed by its members. This form of strategies can be scrutinised from the organising pattern, movement's method, movement's target and movement's medium. The discussion will now turn to each of these aspects of strategy.

Organizing pattern is based on Sikep's central leaders, or what Korver (1976) tends to call as messianistic. In a sense, the founder of the movement itself, Samin Surosentiko (1859-1914), Gunretno and Gunarti of Sedulur Sikep ambiguously play the 'leader' role of the movement, particularly in inciting the members of the movement, as well as spreading the movement through their Javanese tradition of srawung. This way of movement's organising pattern is still strongly related to the way of Sedulur Sikep in organising their community and movement. By having centralised informal figures, Sikep community manages to maintain their role figure who supposedly maintain the values, spirit, and fidelity of the followers. Likewise, Samin and his successors' millenarianistic role, Gunretno and Gunarti became anti-cement idols who are at certain degree responsible to maintain the movement's values and idealism. In order to keep themselves idle, as part of Saminism principles, they are 'appointing' some members of the anti-cement group to be caderised and promoted to lead and deliver the notion of environmental protection and sustainability, as well as communal-based resource governance in all anti-cement group's activities (Dhewy, 2016). These non-Sikep figure appearances in most mainstream media also prove that the anti-cement movement is actually everyone's movement to protect everyone's resources, not merely for Sedulur Sikep or farmers in Pati.

In terms of movement operation method, as aforementioned, the Sikep movement is using non-conventional methods on its oppositional movement. Contemporary Sikep communities, especially those who are involved in the anti-cement movement, 
maintain to perpetuate the values of its colonial Saminism's resistance movement. Thus, their 'resistance identity' for contemporary issues around land exploitation within capitalistic extractivism of cement industries is cantered around non-violent tactics. Anti-cement group operation methods started by recruiting people to join and, or at least, support this movement through the Javanese srawung way. Initially, Gunretno, Gunarti, and some other initiators of the anticement group who strolled from one neighbourhood to another and held srawung, by spreading out the message of environmental conservation, land, and water degradation, future sustainability, also to raise villagers' concern regarding any impact to their future generations, the movement gained many followers and supporters. Simple chat with other farmers during working day in the field perceived to be more effective ways to persuade, partially due to farmers tending to have the same interest on the sustainability of land, water, and other elements of the environment, and partially due to the talk (srawung) performed on field during their agricultural activities, when farmers tend to build stronger connection with the land and Mother Earth. According to Sedulur Sikep who are actively engaged in the anti-cement group, door to door srawung by visiting their neighbor's house also was performed, however usually it was effectively done by having informal gatherings during villagers' evening free time, attended by mostly male villagers, this way of srawung perpetuates the way Samin Surosentiko gathered his followers and did his preaching. To enlarge and fasten the spreading of the issue, the anti-group is also utilising the 'snowball' method of srawung, where recruited villagers are responsible to re-deliver the messages to their neighbors.

In terms of movement's target, it can be said that both the early Sikep movement and today's contemporary anti-cement movement which is at certain point is adapting Saminism are correspondingly 'attacking' the symbols of power and authority. During the colonials era the targets were very clear; forest regulations and the Dutch government officials (Benda \& Castles, 1969; Adas, 
1981; King, 1973; Korver, 1976; Peluso, 1991, 1992), While in present days, Sedulur Sikep communities in Pati and Kudus, in which their members are initiating an anti-cement group, and targeting all entities that have the intention to exploit and capitalising Kendeng Mountains. However, in response to such statements, Sedulur Sikep who are involved in the anti-cement group clarified that their target movement is not the development agenda, or infrastructure-based development praised by the national government, or the idea of cement, for which they admit that they also need cement and concrete. Rather, their target is to stop the continuing exploitation of Kendeng Mountains, especially by big industry such as cement company, which is based on their peasant's traits, where such exploitation will disrupt the water resources underneath Kendeng Mountains that are important for their cultivating activities (Dhewy, 2016).

Movement's medium refers to the type of medium that Sikep movement and anti-cement Saminism-inspired movement use. Both the early colonial period of Sikep movement and the anti-cement Saminism-inspired movement were formed within the issue of common-resources governance, in which both are built upon the notion of a human-earth relationship. Therefore, this movement actually does not specify who should be joining and/or supporting the movement, as long as the same values are shared among them, thus this movement is rather inclusive. Due to the highly political and complex issue in the case of the cement industry, Sedulur Sikep who are initiating and responsible in keeping movement's values, strategies, and its strong image, are lessening - on a certain degree some of the timid idealism of Saminism, so it can attract more people to support and join the movement regardless of their cultural, social, and spiritual beliefs. The inclusive movement then easily is adapting in some specific events in which its member commonly celebrates and/or perform based on their cultural, social, and spiritual beliefs; most of which are subject to Moslem tradition. Therefore, activities by the anti-cement group, especially those that are gathering in mass, 
are usually held under certain Islamic celebrations. In terms of spreading the movement's notion using religious values, it becomes a potent way to spread and actually recruit more members, or just to mainstream the idealism of how the surrounding environment should be protected. The fact that some well-known Islamic elders within the area also support the movement, this anti-cement movement is able to level-up its narratives of resisting the capitalistic cement industries into a movement that protecting what God has given for today and future's generations.

The anti-cement movement indeed includes prominent Sedulur Sikep figures, including well-known Gunretno and Gunarti during its initial formation. Gunretno himself, with his activist background, has contributed his network of Farmers' Union of Pati (SPP) to strengthen the movement. Meanwhile, Gunarti, with her strong spirituality toward Mother Earth, has attracted women to be more actively involved in the movement and stand up for their resources of life: Water and land. Thanks to the active involvement of others figures, both Sikep and non-Sikep alike, through Gunretno and Gunarti's influences, the anti-cement movement had valued and applied the notions of Sikep identities within the movement's norms and idealism.

The aforementioned prominent elements within the narratives of the Kendeng Mountains that are closely related to Sedulur Sikep's identity is the spread of its ideological roots of common resource governance that should be given to the people in all respects, without any interference from authority, more specifically in continuing the 'battle' of the late Samin Surosentiko to oppose any threat to their identity as Javanese peasants, who should be free from any external authority interference, - as argued by Kahin (1955, ss. 43-44):

"[...] the desire of the peasant to be left free to lead their own lives unmolested by government interference and to return to a communalistic social organization based upon economic equality of individuals and upon possession of the land and its products of common (sic)". 
Sedulur Sikep believe that common resources should be managed based on equality of every individual who benefits from its possession and products in common, therefore it should be freed from any capitalisation that only gives exclusive access to certain powerful actors, and leaves others out. At this point, through the Kendeng Mountains, the Sedulur Sikep in Pati inspected their traits of Sikep, which are prone to be exposed to adaptation and evolution. Nevertheless, what the Sedulur Sikep in Pati are trying to avoid is attempts at adaptation and evolution that could incorporate them into the authority-propagated socio-economic order, such as by being subjected to a notion of development driven by the exploitative cement industry and shifting their farmers' lives into industrialisation-based livelihoods.

\section{Conclusion}

The Sikep narratives that permeate within anti-cement groups are based on the belief that the earth (and everything on it) was created by 'God' to fulfill human necessities. They are taught to embrace the earth's resources and avoid taking them for granted, to only take and use based on current needs and without harming the surrounding environment nor interfering with the environments of others. However, the recent capitalisation of common resources, which have either limited or outright closed access to the Kendeng Mountains, has 'awakened' Sedulur Sikep in Pati to the realisation that being only farmers is not enough to keep their land and surrounding environment safe. Therefore, environmental quality has become a critical issue for Sedulur Sikep, not only for the continuity of the Sikep peasant tradition but also for everybody else whose life relies on land and water availability.

It can be said that the Sedulur Sikep in Pati first got involved in the anti-cement movement because of the industry's direct negative impact on their communities. Their awareness and consciousness of these effects, alongside their strong attachment with the Kendeng 
Mountains as their 'source of life', allowed them to find a way to reject the exploitative cement industries.

Built upon the subconscious Sedulur Sikep concept of 'Javanese peasant socialism', the anti-cement group has acknowledged that the Kendeng Mountains should belong to everyone, and shall not be used for someone's private benefit. Thus, it is also everyone's responsibility to keep it sustainable. Therefore, as it is perceived by Sedulur Sikep that every part of the earth is connected without being limited by the administrative borders of villages, districts, or even regencies, Sedulur Sikep considers the Kendeng Mountains which stretch across five regencies as one single entity. Thus, Sedulur Sikep through the anti-cement movement then pledges to keep away any exploitation attempt from the Kendeng Mountains, particularly from big capitalistic industries such as cement companies.

Throughout the anti-cement movement, the narratives of the 'Samin movement' have flared up in a way that re-claims its identity as a group that resists any form of oppression from authority. The Sedulur Sikep have successfully integrated their characteristic resistance into the mainstream movement's narratives in Indonesia, while are also allowing the anti-cement group to receive support and attention from a variety of other actors, especially those who focus on environmental issues and human rights. Moreover, in a broader context of resistance, the anti-cement movement has become a pivotal part of the narrative of grassroots movements versus capitalistic industries supported by the state in Indonesia.

The location of the Kendeng Mountains becomes an important reason for Sedulur Sikep who reject its exploitation. Protecting the mountains from exploitation becomes their way of expressing their Sikep virtues, that later turned into a resistance toward the cement industries. The vernacularisation of the resources, that is the Kendeng Mountains, has, to a significant degree, expressed the Sikep trait of resistance, in such a way that communicates their interests to other related non-Sikep actors, ENGOs, as well as to the local government as the main authority over resource management and in propagating the social, economic, and political order. 


\section{References}

Adas, M. (1981, April). From Avoidance to Confrontation: Peasant Protest in Precolonial and Colonial Southeast Asia. Comparative Studies in Society and History, 23(2), 217-247.

Benda, J. H., \& Castles, L. (1969). The Samin Movement. Bijdragen tot de Taal-, Land-en Volkenkunde, 125, pp. 207-216, 218-240. Retrieved from http://www.jstor.org/stable/27861031

Candraningrum, D. (2014). Politik Rahim Perempuan Kendeng Menolak Tambang Semen. Jurnal Perempuan. Retrieved from https://www. jurnalperempuan.org/blog/dewi-candraningrum-politik-rahimperempuan-kendeng-menolak-tambang-semen

Crosby, A. (2013). Remixing Environmentalism in Blora, Central Java 2005-2010. International Journal of Cultural Studies, 16 (3), 257-269.

Dhewy, A. (2016, Agustus). Gunretno: "Ibu bumi wis maringi, ibu bumi dilarani, ibu kang ngadili". Jurnal Perempuan(21). Retrieved from http://www.jurnalperempuan.org/tokoh/gunretno-ibu-bumiwis-maringi-ibu-bumi-dilarani-ibu-bumi-kang-ngadili

Escobar, A. (1995). Encountering Development. Princeton and Oxford: princeton University Press.

Heryanto, A. (1999). Where Communism Never Dies: Violence, Trauma and Narration in the Last Cold War Capitalist Authoritarian State. International Journal of Cultural Studies, 2 (2), 147-177.

Irwin, A. (1995). Citizen Science: A Study of People, Expertise and Sustainable Development. London : Routledge.

JMPPK. (2015). Rencana Pembangunan Pabrik Semen PT. SMS: Catatan Kritis Masyarakat Kendeng. Pati: JMPPK - Jaringan Masyarakat Peduli Pegunungan Kendeng.

Kahin, G. M. (1955). Nationalism and Revolution in Indonesia. Ithaca, New York: Cornell University Press.

Kartodirdjo, S. (1972). Agrarian Radicalism in Java: Its Setting and Development. In C. Holt (Ed.), Culture and Politics in Indonesia (pp. 71-125). Jakarta and Kuala Lumpur: Equinox Publisher.

King, V. T. (1973). Some Observations on The Samin Movement of North-Central Java: Suggestions for The Theoritical Analysis of The Dynamics of Rural Unrest. Bijdragen tot de Taal-, Land-en Volkenkunde(129), 457-481. Retrieved from http://www.jstor.org/ stable/27861364

Korver, A. P. (1976). The Samin Movement and Millenarism. Bijdragen tot de Taal-, Land-en Volkenkunde, 249-266. Retrieved from http:// www.jstor.org/stable/27863055

Peluso, N. (1991). The History of State Forest Management in Colonial 
Java. Forest \& Conservation History, 65-75.

Peluso, N. (1992). Rich Forest, Poor People. Berkeley and Los Angeles: University of California Press.

Pulido, L. (1998). The Sacredness of "Mother Earth": Spirituality, Activism, and Social Justice. Annals of the Association of American Geographers, 88(4), 719-723.

Ross, C. (2017). Ecology and Power in the Age of Empire: Europe and the Transformation of the Tropical World. New York: Oxford University Press.

Scott, J. C. (1977). Protest and Profanation: Agrarian Revolt and the LIttle Tradition, Part II. Theory and Society 4(2), 211-246. Retrieved from http://www.jstor.org/stable/656831

Scott, J. C. (1985). Weapons of the Weak, Everyday Forms of Peasant Resistance. New Haven and London: Yale University Press.

Shiraishi, T. (1990, October). Dangir's Testimony: Saminism Reconsidered. Indonesia (25th Anniversary Edition) (50), 95-120.

Strachan, L. (2003). Political Ecology and Identity: A Study of the Harasiis of Oman. Totem: The University of Western Ontario Journal of Anthropology, 101-113.

Susanto, A. (2016, April 20). Perempuan Sikep Menjaga Pegunungan Kendeng Utara. Retrieved August 18, 2016, from http://www.rappler.com/ indonesia/130127perempuansikepjagapegunungankarstkendengu tara

Thorburn, C. (2002). Regime Change - Prospects for Community-based Resource Management in Post-New Order Indonesia. Society and Natural Resources , 617-628.

Widodo, A. (1997). Samin in the New Order: the Politics of Encounter and Isolation. In J. Schiller, \& B. Martin-Schiller (Eds.), Imagining Indonesia: Cultural Politics and Politics Culture (pp. 261-287). Athens, Ohio: Ohio University Press.

Yeh, E. T., \& Bryan, J. (2015). Indigeneity. In T. Perreault, G. Bridge, \& J. McCarthy (Eds.), The Routledge Handbook of Political Ecology (pp. 531-539). London: Routledge. 